\title{
Proposal for transfer of Pelagibacillus goriensis Kim et al. 2007 to the genus Terribacillus as Terribacillus goriensis comb. nov.
}

Correspondence

T. Chakrabarti

tapan@imtech.res.in

\author{
Srinivasan Krishnamurthi and T. Chakrabarti
}

Microbial Type Culture Collection \& Gene Bank (MTCC), Institute of Microbial Technology, Sector 39A, Chandigarh 160 036, India
In the course of a study of bacterial and archaeal diversity of a landfill site, many bacteria were isolated and characterized. During this process, a strain designated $3 \mathrm{LF} 22 \mathrm{~T}$ was found to show $99.8 \% 16 \mathrm{~S}$ rRNA gene sequence similarity to two recently described novel taxa, Terribacillus saccharophilus (An et al., 2007) and Pelagibacillus goriensis (Kim et al., 2007). Because of sequence similarity of strain $3 \mathrm{LF} 22 \mathrm{~T}$ with these two taxa, we examined their taxonomic positions. On the basis of the data available, we propose the unification of the two genera and the transfer of the sole species of the genus Pelagibacillus to the genus Terribacillus.

The genera Terribacillus and Pelagibacillus belong to Bacillus group 1 (Ash et al., 1991), along with many halophilic and halotolerant members of genera like Halobacillus (Spring et al., 1996), Virgibacillus (Heyndrickx et al., 1998), Gracilibacillus (Wainø et al., 1999), Oceanobacillus (Lu et al., 2001), Filobacillus (Schlesner et al., 2001), Lentibacillus (Yoon et al., 2002), Paraliobacillus (Ishikawa et al., 2002), Tenuibacillus (Ren \& Zhou, 2005a), Pontibacillus (Lim et al., 2005), Salinibacillus (Ren \& Zhou, 2005b), Thalassobacillus (Garcia et al., 2005), Halolactibacillus (Ishikawa et al., 2005), Ornithinibacillus (Mayr et al., 2006) and Paucisalibacillus (Nunes et al., 2006). These bacteria either do not grow or grow very weakly without added salt in the medium, but growth is stimulated by the addition of salt.
The $16 \mathrm{~S}$ rRNA gene sequences of Terribacillus saccharophilus $002-048^{\mathrm{T}}$, Terribacillus halophilus $002-051^{\mathrm{T}}$ and Pelagibacillus goriensis CL-GR $16^{\mathrm{T}}$ were retrieved from the NCBI nucleotide database. In order to decipher the exact taxonomic position of the three strains, we also retrieved the 16S rRNA gene sequences of 17 type species of other halophilic/halotolerant genera of Bacillus group 1 along with sequences of other representative members of Bacillus groups 1 and 2, aligned them using the CLUSTAL_X software (Thompson et al., 1997) and edited the alignment manually. Pairwise sequence similarities were calculated using the BioEdit software package (Hall, 1999). A continuous stretch of 1389 nucleotides without any ambiguous bases or gaps was used to construct a phylogenetic tree based on the algorithm of Jukes \& Cantor (1969) using the neighbourjoining method (Saitou \& Nei, 1987) and with the TREECON software package (Van de Peer \& De Wachter, 1997). The topology of the constructed tree was evaluated using 1000 replicates. A tree based on the maximum-parsimony method was also constructed using the PHYLIP software package version 3.5c (Felsenstein, 1993). DNA-DNA hybridization was performed between $P$. goriensis DSM $18252^{\mathrm{T}}$ and its phylogenetically close relatives T. saccharophilus JCM $21759^{\mathrm{T}}$ and T. halophilus JCM $21760^{\mathrm{T}}$ using the membrane filter method (Tourova \& Antonov, 1987) as described by Reddy et al. (2003). 
Analysis of $16 \mathrm{~S}$ rRNA gene sequences indicated that $P$. goriensis KCCM $42329^{\mathrm{T}}$ shared a high degree of sequence similarity $(99.8 \%)$ with T. saccharophilus IAM $15309^{\mathrm{T}}$, the type strain of the type species of the genus Terribacillus, and $98.9 \%$ with $T$. halophilus IAM $15310^{\mathrm{T}}$. This high level of sequence similarity is generally not observed between strains belonging to different genera (Ludwig et al., 1998). The three strains showed relatively low sequence similarity to other halophilic and halotolerant bacilli like Ornithinibacillus bavariensis (a maximum of $94.7 \%$ similarity to the type strain), Salirhabdus euzebyi (94.3\%), Paucisalibacillus globulus (94.2\%), Salinibacillus aidengensis (93.9\%) and Oceanobacillus picturae (93.8\%) and less than $93.0 \%$ to other members of Bacillus rRNA group 1. As shown in Fig. 1, the three strains along with strain $3 \mathrm{LF} 22 \mathrm{~T}$ formed a distinct and tight cluster supported by a high bootstrap value of $100 \%$, thus emphasizing the fact that these four strains are phylogenetically closely related. A tree constructed using the maximum-parsimony method showed a similar topology (refer to Fig. 1). Moreover, members of these two genera also share many phenotypic characteristics (Table 1). For example, T. saccharophilus and $P$. goriensis have similar fatty acid profiles, with anteiso- $\mathrm{C}_{15: 0}$ as the major fatty acid followed by anteiso- $\mathrm{C}_{17: 0}$ and iso- $\mathrm{C}_{15: 0}$, similar major menaquinones (MK-7) and similar $\mathrm{G}+\mathrm{C}$ contents (Table 1). These data support the results of phylogenetic analyses that the taxonomic position of the genus Pelagibacillus needs re-examination, and we propose that $P$. goriensis be transferred as a species of the genus Terribacillus. DNA-DNA hybridization of $P$. goriensis DSM $18252^{\mathrm{T}}$ with T. saccharophilus JCM $21759^{\mathrm{T}}$ and $T$. halophilus JCM $21760^{\mathrm{T}}$ was 51.7 and $35.6 \%$, respectively.
Since the genomic relatedness is below the value of $70 \%$ recommended for delineation of bacterial species (Wayne et al., 1987), P. goriensis should be treated as a separate species within the genus Terribacillus. Results of DNADNA hybridization studies also revealed that strain $3 \mathrm{LF}$ $22 \mathrm{~T}$ shared $79.8 \%$ similarity at the genomic level with $P$. goriensis DSM $18252^{\mathrm{T}}$ and $26.2 \%$ with $T$. saccharophilus JCM $21759^{\mathrm{T}}$. Although $P$. goriensis and T. saccharophilus share a number of characteristics (Table 1), they differ in some phenotypic traits like the Voges-Proskauer test, $\beta$ galactosidase activity, optimal $\mathrm{NaCl}$ concentration for growth, acid production from melibiose and utilization of D-xylose, D-glucose, D-fructose, sucrose, glycerol and mannitol. These differences in phenotypic properties may be used to delineate the two taxa.

Reclassifications such as that proposed here may be required when two different research groups working on novel strains at the same time communicate their manuscripts for publication at about the same time. It appears that, in this case, the two research groups would probably not have known which of the strains was going to be described first, as the database containing the sequence information would have displayed them as unpublished at that time. A similar situation arose when the same strain, ATCC 19623 (originally described as a strain of Zooglea ramigera), was described almost simultaneously as a member of the novel genera Crabtreella (Xie \& Yokota, 2006) and Shinella (An et al., 2006); Crabtreella saccharophila is a later homotypic synonym of Shinella zoogloeoides (http://www.bacterio.cict.fr/c/crabtreella.html). It is therefore quite possible that these situations can arise inadvertently.

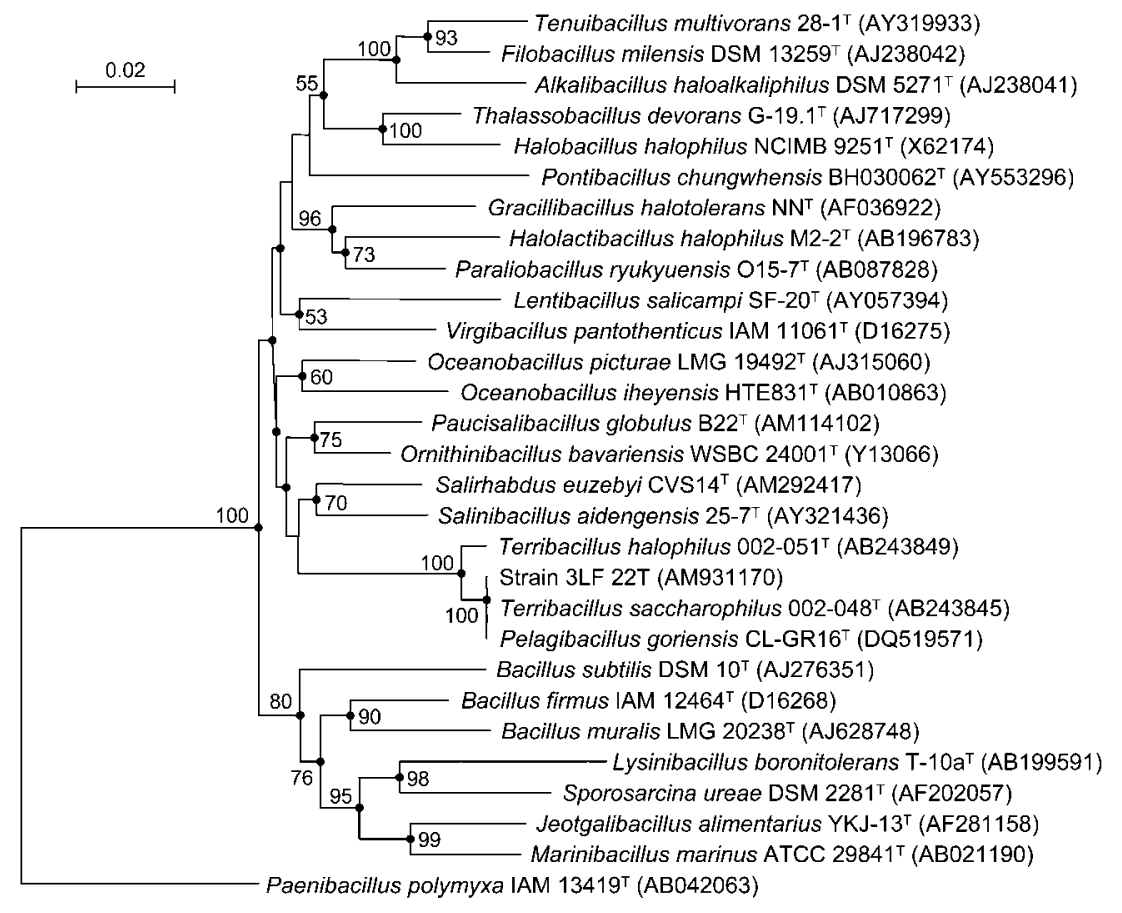

Fig. 1. Phylogenetic tree based on $16 \mathrm{~S}$ rRNA gene sequences and reconstructed using the neighbour-joining method showing the relationship between $T$. saccharophilus, P. goriensis and closely related genera. Bootstrap values $>50 \%$ are shown at nodes as percentages of 1000 replications. The sequence from Paenibacillus polymyxa IAM $13419^{\top}$ was used as an outgroup. Bar, 0.02 substitutions per site. Dots indicate nodes that were also recovered using the maximum-parsimony method. 
Table 1. Comparative phenotypic characteristics of the type strains of $T$. saccharophilus, T. halophilus and $P$. goriensis

Strains: 1, T. saccharophilus 002-048 ${ }^{\mathrm{T}}$ (data from An et al., 2007) 2, P. goriensis CL-GR16 ${ }^{\mathrm{T}}$ (Kim et al., 2007); 3 , T. halophilus $002-051^{\mathrm{T}}$ (An et al., 2007). The three strains share many characteristics such as swollen sporangia, no requirement for $\mathrm{NaCl}$ for growth, being positive for catalase activity and gelatin hydrolysis and being negative for oxidase activity, anaerobic growth, reduction of nitrate, $\mathrm{H}_{2} \mathrm{~S}$ production, arginine dihydrolase, lysine decarboxylase, tryptophan deaminase, urease and indole production. All three strains have MK-7 as their major menaquinone. Fatty acids that were present in amounts less than $0.5 \%$ in all three strains are not shown. NA, Data not available; w, weakly positive.

\begin{tabular}{|c|c|c|c|}
\hline Characteristic & 1 & 2 & 3 \\
\hline Spore shape ${ }^{\star}$ & $E, S$ & $\mathrm{E}$ & $\mathrm{E}, \mathrm{S}$ \\
\hline Spore position $\dagger$ & ST, $\mathrm{T}$ & C, ST & $S T, T$ \\
\hline Motility & - & + & - \\
\hline Voges-Proskauer test & + & - & + \\
\hline \multicolumn{4}{|l|}{ Acid production from: } \\
\hline Amygdalin, melibiose & - & + & - \\
\hline Glucose, sucrose & + & + & - \\
\hline Rhamnose & - & $\mathrm{w}$ & - \\
\hline \multicolumn{4}{|l|}{ Utilization of: } \\
\hline L-Arabinose & - & - & + \\
\hline Citrate, xylose & - & + & - \\
\hline D-Fructose, D-glucose, glycerol, mannitol, sucrose & + & - & + \\
\hline Galactose, raffinose, trehalose & + & + & - \\
\hline Melibiose & + & NA & - \\
\hline Production of $\beta$-galactosidase & - & + & - \\
\hline Growth temperature range $\left({ }^{\circ} \mathrm{C}\right)$ & $5-45$ & $15-43$ & $5-45$ \\
\hline $\mathrm{pH}$ range for growth & $6-10$ & $5.5-9.0$ & $5-10$ \\
\hline \multicolumn{4}{|l|}{$\mathrm{NaCl}$ concentration for growth $(\% \mathrm{w} / \mathrm{v})$} \\
\hline Range & $0-16$ & $0-14$ & $0-19$ \\
\hline Optimum & $1-5$ & $0-2$ & $1-5$ \\
\hline DNA G $+C$ content $(\mathrm{mol} \%)$ & 44.0 & 43.0 & 45.8 \\
\hline \multicolumn{4}{|l|}{ Fatty acids $(\%)$} \\
\hline $\mathrm{C}_{14: 0}$ & 1.2 & 1.9 & 1.4 \\
\hline $\mathrm{C}_{15: 0}$ & $\mathrm{NA}$ & 0.7 & $\mathrm{NA}$ \\
\hline$C_{16: 0}$ & 1.3 & 2.9 & 1.4 \\
\hline $\mathrm{C}_{14: 1} \omega 5 c$ & $\mathrm{NA}$ & 0.8 & $\mathrm{NA}$ \\
\hline iso- $\mathrm{C}_{14: 0}$ & 2.3 & 2.6 & 1.1 \\
\hline iso- $\mathrm{C}_{15: 0}$ & 7.6 & 9.1 & 5.6 \\
\hline anteiso- $\mathrm{C}_{15: 0}$ & 63.5 & 65.6 & 47.6 \\
\hline iso- $\mathrm{C}_{16: 0}$ & 5.5 & 4.2 & 5.3 \\
\hline anteiso- $\mathrm{C}_{17: 0}$ & 17.9 & 11.0 & 34.8 \\
\hline iso- $\mathrm{C}_{17: 0}$ & 0.7 & 0.4 & 1.1 \\
\hline
\end{tabular}

${ }^{\star}$ E, Ellipsoidal; s, spherical.

$\nmid \mathrm{C}$, Central; ST, subterminal; T, terminal.

\section{Emended description of the genus Terribacillus An et al. 2007}

Terribacillus [Ter.ri.ba.cil'lus. L. n. terra earth; L. masc. n. bacillus a small staff; N.L. masc. n. Terribacillus earth (soil) bacillus (rod)].

The description of the genus is the same as that given by An et al. (2007). In addition, the cells may be motile or non-motile and $\beta$-galactosidase-positive or -negative. The Voges-Proskauer test may be positive or negative. The DNA G $+\mathrm{C}$ content is in the range $43.0-$ $46.0 \mathrm{~mol} \%$.

\section{Description of Terribacillus goriensis (Kim et al. 2007) comb. nov.}

Terribacillus goriensis (go.ri.en'sis. N.L. masc. adj. goriensis from Gori, where the type strain was isolated).

Basonym: Pelagibacillus goriensis Kim et al. 2007. 
The description is the same as that given for Pelagibacillus goriensis by Kim et al. (2007).

\section{Acknowledgements}

Financial assistance from DBT, Government of India, and CSIR is duly acknowledged. S. K. is a recipient of a CSIR fellowship. This is IMTECH communication number 034/2007. We are thankful to the Japan Collection of Microorganisms, the Deutsche Sammlung von Mikroorganismen und Zellkulturen and the Korean Culture Center of Microorganisms for generous gifts of the type strains. We thank the anonymous reviewers for their constructive suggestions on the manuscript. We also thank Dr Jean Euzéby for his advice on nomenclature.

\section{References}

An, D. S., Im, W. T., Yang, H. C. \& Lee, S. T. (2006). Shinella granuli gen. nov., sp. nov., and proposal of the reclassification of Zoogloea ramigera ATCC 19623 as Shinella zoogloeoides sp. nov. Int J Syst Evol Microbiol 56, 443-448.

An, S. Y., Asahara, M., Goto, K., Kasai, H. \& Yokota, A. (2007). Terribacillus saccharophilus gen. nov., sp. nov. and Terribacillus halophilus sp. nov., spore-forming bacteria isolated from field soil in Japan. Int J Syst Evol Microbiol 57, 51-55.

Ash, C., Farrow, J. A. E., Wallbanks, S. \& Collins, M. D. (1991). Phylogenetic heterogeneity of the genus Bacillus revealed by comparative analysis of small subunit ribosomal RNA sequences. Lett Appl Microbiol 13, 202-206.

Felsenstein, J. (1993). PHYLIP (phylogeny inference package), version 3.5c. Distributed by the author. Department of Genome Sciences, University of Washington, Seattle, USA.

Garcia, M. T., Gallego, V., Ventosa, A. \& Mellado, E. (2005). Thalassobacillus devorans gen. nov., sp. nov., a moderately halophilic, phenol-degrading, Gram-positive bacterium. Int J Syst Evol Microbiol 55, 1789-1795.

Hall, T. A. (1999). BioEdit: a user-friendly biological sequence alignment editor and analysis program for Windows 95/98/NT. Nucleic Acids Symp Ser 41, 95-98.

Heyndrickx, M., Lebbe, L., Kersters, K., De Vos, P., Forsyth, C. \& Logan, N. A. (1998). Virgibacillus: a new genus to accommodate Bacillus pantothenticus (Proom and Knight 1950). Emended description of Virgibacillus pantothenticus. Int J Syst Bacteriol 48, 99-106.

Ishikawa, M., Ishizaki, S., Yamamoto, Y. \& Yamasato, K. (2002). Paraliobacillus ryukyuensis gen. nov., sp. nov., a new Gram-positive, slightly halophilic, extremely halotolerant, facultative anaerobe isolated from a decomposing marine alga. J Gen Appl Microbiol 48, 269-279.

Ishikawa, M., Nakajima, K., Itamiya, Y., Furukawa, S., Yamamoto, Y. \& Yamasato, K. (2005). Halolactibacillus halophilus gen. nov., sp. nov. and Halolactibacillus miurensis sp. nov., halophilic and alkaliphilic marine lactic acid bacteria constituting a phylogenetic lineage in Bacillus rRNA group 1. Int J Syst Evol Microbiol 55, 2427-2439.

Jukes, T. H. \& Cantor, C. R. (1969). Evolution of protein molecules. In Mammalian Protein Metabolism, vol. 3, pp. 21-132. Edited by H. N. Munro. New York: Academic Press.

Kim, Y. G., Hwang, C. Y., Yoo, K. W., Moon, H. T., Yoon, J. H. \& Cho, B. C. (2007). Pelagibacillus goriensis gen. nov., sp. nov., a moderately halotolerant bacterium isolated from coastal water off the east coast of Korea. Int J Syst Evol Microbiol 57, 1554-1560.
Lim, J. M., Jeon, C. O., Song, S. M. \& Kim, C. J. (2005). Pontibacillus chungwhensis gen. nov., sp. nov., a moderately halophilic Grampositive bacterium from a solar saltern in Korea. Int J Syst Evol Microbiol 55, 165-170.

Lu, J., Nogi, Y. \& Takami, H. (2001). Oceanobacillus iheyensis gen. nov., sp. nov., a deep-sea extremely halotolerant and alkaliphilic species isolated from a depth of $1050 \mathrm{~m}$ on the Iheya Ridge. FEMS Microbiol Lett 205, 291-297.

Ludwig, W., Strunk, O., Klugbauer, S., Klugbauer, N., Weizenegger, M., Neumaier, J., Bachleitner, M. \& Schleifer, K. H. (1998). Bacterial phylogeny based on comparative sequence analysis. Electrophoresis 19, 554-568.

Mayr, R., Busse, H.-J., Worliczek, H. L., Ehling-Schulz, M. \& Scherer, S. (2006). Ornithinibacillus gen. nov., with the species Ornithinibacillus bavariensis sp. nov. and Ornithinibacillus californiensis sp. nov. Int J Syst Evol Microbiol 56, 1383-1389.

Nunes, I., Tiago, I., Pires, A. L., da Costa, M. S. \& Veríssimo, A. (2006). Paucisalibacillus globulus gen. nov., sp. nov., a Gram-positive bacterium isolated from potting soil. Int J Syst Evol Microbiol 56, 1841-1845.

Reddy, G. S. N., Matsumuto, G. I. \& Shivaji, S. (2003). Sporosarcina macmurdoensis sp. nov., from a cyanobacterial mat sample from a pond in the McMurdo Dry Valleys, Antarctica. Int J Syst Evol Microbiol 53, 1363-1367.

Ren, P. G. \& Zhou, P. J. (2005a). Tenuibacillus multivorans gen. nov., sp. nov., a moderately halophilic bacterium isolated from saline soil in Xin-Jiang, China. Int J Syst Evol Microbiol 55, 95-99.

Ren, P. G. \& Zhou, P. J. (2005b). Salinibacillus aidingensis gen. nov., sp. nov. and Salinibacillus kushneri sp. nov., moderately halophilic bacteria isolated from a neutral saline lake in Xin-Jiang, China. Int $J$ Syst Evol Microbiol 55, 949-953.

Saitou, N. \& Nei, M. (1987). The neighbor-joining method: a new method for reconstructing phylogenetic trees. Mol Biol Evol 4, 406-425.

Schlesner, H., Lawson, P. A., Collins, M. D., Weiss, N., Wehmeyer, U., Volker, H. \& Thomm, M. (2001). Filobacillus milensis gen. nov., sp. nov., a new halophilic spore-forming bacterium with Orn-D-Glu-type peptidoglycan. Int J Syst Evol Microbiol 51, 425-431.

Spring, S., Ludwig, W., Marquez, M. C., Ventosa, A. \& Schleifer, K. H. (1996). Halobacillus gen. nov., with descriptions of Halobacillus litoralis sp. nov. and Halobacillus trueperi sp. nov., and transfer of Sporosarcina halophila to Halobacillus halophilus comb. nov. Int J Syst Bacteriol 46, 492-496.

Thompson, J. D., Gibson, T. J., Plewniak, F., Jeanmougin, F. \& Higgins, D. G. (1997). The CLUSTAL_X windows interface: flexible strategies for multiple sequence alignment aided by quality analysis tools. Nucleic Acids Res 25, 4876-4882.

Tourova, T. P. \& Antonov, A. S. (1987). Identification of microorganisms by rapid DNA-DNA hybridization. Methods Microbiol 19, 333-355.

Van de Peer, Y. \& De Wachter, R. (1997). Construction of evolutionary distance trees with TREECON for Windows: accounting for variation in nucleotide substitution rate among sites. Comput Appl Biosci 13, 227-230.

Wainø, M., Tindall, B. J., Schumann, P. \& Ingvorsen, K. (1999), Gracilibacillus gen. nov., with description of Gracilibacillus halotolerans gen. nov., sp. nov.; transfer of Bacillus dipsosauri to Gracilibacillus dipsosauri comb. nov., and Bacillus salexigens to the genus Salibacillus gen. nov., as Salibacillus salexigens comb. nov. Int J Syst Bacteriol 49, 821-831.

Wayne, L. G., Brenner, D. J., Colwell, R. R., Grimont, P. A. D., Kandler, O., Krichevsky, M. I., Moore, L. H., Moore, W. E. C., Murray, R. G. E. \& other 
authors (1987). International Committee on Systematic Bacteriology. Report of the ad hoc committee on reconciliation of approaches to bacterial systematics. Int J Syst Bacteriol 37, 463-464.

Xie, C. H. \& Yokota, A. (2006). Zoogloea oryzae sp. nov., a nitrogenfixing bacterium isolated from rice paddy soil, and reclassification of the strain ATCC 19623 as Crabtreella saccharophila gen. nov., sp. nov. Int J Syst Evol Microbiol 56, 619-624.

Yoon, J. H., Kang, K. H. \& Park, Y. H. (2002). Lentibacillus salicampi gen. nov., sp. nov., a moderately halophilic bacterium isolated from a salt field in Korea. Int J Syst Evol Microbiol 52, 2043-2048. 